\title{
SUBCELLULAR DISTRIBUTION OF ASCORBIC ACID IN RAT BRAIN
}

\author{
Che-Hui KUO, Norifumi YONEHARA, Fumiaki HATA \\ and Hiroshi YOSHIDA \\ Department of Pharmacology I, Osaka University, School of Madicine, \\ Kita-ku, Osaka 530, Japan
}

Accepted June 15, 1978

It is well documented that influx of $\mathrm{Ca}$ ion to the nerve terminal induces a release of acetylcholine ( $\mathrm{ACh}$ ), the nerve transmitter (1). One of the sites of action of $\mathrm{Ca}^{++}$in the nerve terminal is considered to be on synaplic vesicles which store ACh. Accordingly, we isolated the synaptic vesicles from the rat brain and conditions which would induce a release of $\mathrm{ACh}$ from the vesicles responding to low concentration of $\mathrm{Ca}^{+1}$ were examined. As we have already reported, $\mathrm{Ca}^{++}$dependent $\left(10^{-6} \mathrm{M}\right) \mathrm{ACh}$ release from the synaptic vesicles was enhanced by the addition of sap (synaptosomal cytoplasma) in the presence of ATP and $\mathrm{Mg}^{++}(2-3)$. The factor in the sap was then purified by column chromatography and was identified to be ascorbic acid, with UV-spectrum in various pH conditions, and cellulose thin layer chromatography. During the above experiments, we observed that the releusing effects of sap were more remarkable than that of the cytoplasma in the cell body. Distribution of ascorbic acid in the subcellular fractions of rat brain was examined herein.

Subcellular fractionation was carried out by method of Whittaker et al. (4) with a slight modification as follows: whole brains of adult healthy S.D. rats were homogenized with 5 vol of $0.32 \mathrm{M}$ sucrose and the soluble fraction $\left(\mathrm{S}_{1}\right)$ was obtained by centrifugation at $1,000 \times \mathrm{g}$ for 10 min. Then $S_{1}$ fraction was centrifuged at $12,000 \mathrm{~g}$ for 40 min 10 obtain particle $\left(\mathrm{P}_{2}\right)$ and soluble $\left(\mathrm{S}_{2}\right)$ fractions. After hypotonic treatment of $\mathrm{P}_{2}$ fraction with water $(4 \mathrm{ml} / \mathrm{g}$ tissue), centrifuged at $100,000 \times \mathrm{g}$ was carried out for $40 \mathrm{~min}$ and soluble $\left(\mathrm{P}_{2} \mathrm{~s}\right)$ and particle $\left(P_{2} p\right)$ fractions were obtained. Microsome and $S_{3}$ fractions were obtained by centrifugation of $\mathrm{S}_{2}$ at $100,000 \times \mathrm{g}$ for $40 \mathrm{~min}$. Content of ascorbic acid in cach fraction was determined with 2,4-dinitrophynylhydrazine by method of Lowry et al. (5) and protcin were measured according to method of Lowry et al. (6).

Content of ascorbic acid in rat brain homogenate was $357.3 \pm 21.9 / \mathrm{g} / \mathrm{g}$ tissue and this value is in agreement with the results of Subramanian (7). Table 1 shows the subcellular distribution of protein and ascorbic acid per $g$ wet weight of the rat brain. As shown in Table 1, fraction $P_{2} s_{2}$ synaptosomal cytoplasm, exhibited the highest specific content of ascorbic acid ( $\mu \mathrm{g} / \mathrm{nng}$ protein) among the subfractions. $S_{3}$ had also high specific content, but significantly less than $\mathrm{P}_{2}$ s. Particles had little ascorbic acid.

Ascorbic acid is well known to be an anti-scurvy vitamin, but its physiological role in brain function is unknown. Ascorbic acid was found in the brain in the highest concentration, except for the adrenals (8), and it was reported that ascorbic acid was taken up by the brain 
TABLE 1. Subcellular distribution of ascorbic acid in rat brain

\begin{tabular}{cccc}
\hline & mg protein/g & $\mu$ ascorbic acid/g & $\begin{array}{c}\text { tg ascorbic } \\
\text { acid/mg prot }\end{array}$ \\
\hline Homogenate & $108.1 \pm 16.6$ & $357.3 \pm 21.9$ & $3.4 \pm 0.6$ \\
$P_{1}$ & $79.5 \pm 13.6$ & $190.6 \pm 9.8$ & $2.4 \pm 0.3$ \\
$\mathrm{~S}_{1}$ & $30.8 \pm 3.2$ & $150.4 \pm 10.4$ & $4.9 \pm 0.2$ \\
$\mathrm{P}_{2}$ & $13.3 \pm 1.1$ & $32.1 \pm 5.6$ & $2.5 \pm 0.4$ \\
$\mathrm{~S}_{2}$ & $12.3 \pm 3.2$ & $116.4 \pm 23.0$ & $9.6 \pm 0.9$ \\
$\mathrm{P}_{2 \mathrm{p}}$ & $9.6 \pm 1.0$ & $2.5+0.3$ & $0.3 \pm 0.1$ \\
$\mathrm{P}_{2} \mathrm{~S}$ & $2.4 \pm 0.4$ & $36.7 \pm 8.2$ & $15.5 \pm 1.9^{*}$ \\
Microsome & $1.8 \pm 0.4$ & $3.7 \pm 1.7$ & $2.0 \pm 0.5$ \\
$\mathrm{~S}_{3}$ & $9.9 \pm 2.8$ & $104.3 \pm 19.9$ & $10.8 ! 1.0^{*}$ \\
\hline *** Recovery $(\%)$ & $95.8 \pm 6.2$ & $94.6 \pm 2.2$ & \\
\hline
\end{tabular}

The results are the mean $\perp$ S.D. of 4 experiments. *Significantly different between contents of ascorbic acid in $P_{2} s$ and $S_{3}$ fractions $(p<0.025) . \quad{ }^{*} \mathrm{P}_{1}+\mathrm{P}_{2} \mathrm{p}+\mathrm{P}_{2} \mathrm{~S}+$ microsome $+\mathbf{S}_{3}$

from plasma by a carrier mediated, energy-dependent and stereospecific transport system (9). Furthermore, other workers found that vitamin $\mathrm{C}$ participates in synthesis and storage of catecholamine (10-11), and in vitamin $\mathrm{C}$ deficient states, significant changes in the amount of catecholamines in the brain have also been reported (12). In our laboratory we found that the low concentration of $\mathrm{L}$-ascorbic acid $\left(5 \times 10^{-6} \mathrm{M}\right)$ induced a $\mathrm{Ca}^{++}$-dependent $\left(10^{-6}\right.$ $\left.10^{-5} \mathrm{M}\right) \mathrm{ACh}$ release from the isolated synaptic vesicles in the presence of ATP and $\mathrm{Mg}^{++}$. These results indicate that ascorbic acid may be associated with the function of the nervous system, particularly with dynamic states of transmitters in the nerve terminals. Under physiological conditions, concentration of ascorbic acid in the brain was found to be over $2 \mathrm{mM}$, such levels being sufficient for ACh release. Accordingly the ACh release from the vesicles is considered to be physiologically regulated by $\mathrm{Ca}^{++}$.

\section{REFERENCES}

1) MiLed, R.: Transmitter release induced by injection of calcium ions into nerve terminals. Proc. R. Soc. Lond. B. 183, 421-425 (1973); 2) Hata, F., Kuo, C.-H., Matsuda, T. And Yoshida, H.: Factors required for Ca-sensitive acetylcholine release from crude synaptic vesicles. $J$. Neurochem. 27, 139-144 (1976); 3) Kuo, C.-H., ICHIDA, S., HATA, F. and Yoshida, H.: Effects of synaptic plasma membranes on release of acelylcholine from synaptic vesicles. Japan. J. Pharmacol. 28, 339-343 (1978); 4) Whittaker, V.P., Michaelson, I.A. and Kirkland, R.J.A.: The separation of synaptic vesicles from nerve-ending particles ("Synaptosome"). Biochem. J. 90, 293-303 (1964); 5) LOWRY, O.H., Lopf7, J.A. AND BesSEY, O.A.: The determination of ascorbic acid in small amounts of blood serum. J. biol. Chem. 160, 609-615 (1947); 6) LowRY, O.H., Rosebrough, N.J., Farr, A.L. and Randali, R.J.: Protein measurements with the Folin phenol reagent. $J$. biol. Chem. 193, 265-275 (1951); 7) Subramanian, N.: On the brain ascorbic acid and its importance in metabolism of biogenic amines. Life Sci. 20, 1479-1484 (1977); 8) Y Avorskr, M., Almaden, P. And King, C.G.: The vitamine C content of human tissues. J. biol, Chem. 106, 525-529 (1934); 9) SPECTOR, R. AND LoRlzo, A.V.: Specificity of ascorbic acid transport system of the central nervous system. Am. J. Physiol. 226, 1468-1473 (1974); 10) THOA, N.B., WURTMAN, R.J. AND AXELROD, J.: A delicient binding mechanism for norepinephrine in hearts of scorbic guinea pigs. Proc. Soc. exp. Biol. Med. 121, 268-270 (1966); 11) SEARs, M.L.: Vitamin $\mathrm{C}$ as a requirement for the storage of norepinephrine by the iris. Biochem. Pharmacol. 18, 253-256 
(1969); 12) Deana, R., Bharaj, B.S., Verjee, Z.H. and Galzigna, L.: Changes relevant to catecholamine metabolism in liver and brain of ascorbic acid deficient guinea-pigs. Int. J. Vit. Nutr. Res. 45, 175-182 (1975)

\title{
THE OXYTOCIC EFFECT OF CENTRALLY INJECTED PROSTAGLANDINS $E_{2}$ AND $F_{2 a}$
}

\author{
Seigo FUJIMOTO, Shiro HISADA and Hiromi TSUSHIMA \\ Department of Pharmacolory, Nagoya City University Medicul School. \\ Kawawmi, Mizuho-ku, Nagoya 467, Japan
}

Accepted June 26, 1978

Centrally administered prostaglandins (PGs) released hypothalamic and pituitary hormones including antidiurctic hormone $(\mathrm{ADH})$ in rats $(1,2)$. The present authors reported that $P G E_{2}$ and $P G F_{2, x}$, when injected into the lateral ventricle produced diuresis followed by antidiuresis in ethanol anaesthetized rats (3). Centrally injected PGA also changed urine outflow in the rat (4). On the other hand, little attention has been paid to effect of centrally injected PGs on oxytocin release, although Prilusky and Deis (5) did suggest that i.p. administration of $\mathrm{PGF}_{2 \alpha}$ inhibited milk-ejection by a central block on oxytocin release in lactating rats and Cobo $e t$ al. (6) suggested that the milk-ejecting activity of i.v. administered $\mathrm{PGF}_{2 \varsigma}$ in lactating women was mediated through the central release of oxytocin.

In the present study, an attempt was made to determine whether or not centrally administered $\mathrm{PGE}_{2}$ and $\mathrm{PGF}_{2 \alpha}$ were oxytocic in rats. Virgin Wistar rats, weighing 200-250 $\mathrm{g}$ were used. The sexual stage of the rat was determined by taking a vaginal smear in the morning before the rat was selected for the experiment. Ethanol was used as the anaesthetic according to method of Krejci et al. (7). Essentially, anaesthesia was induced by oral administration of $12 \%$ ethanol in a volume of $5 \mathrm{ml} / 100 \mathrm{~g}$ and maintained with i.v. infusion of $3 \%$ cthanol at a rate of $0.1 \mathrm{ml} / \mathrm{min}$. The technique for recording the spontaneous motility of the uterus was as described elsewhere (8). Briefly, the horn of one uterus was cannulated with a polyethylene tubing filled with saline and the spontaneous motility of the uterus as reflected in the intrauterine pressure was recorded through a pressure transducer on a polygraph. A base line pressure of $30-40 \mathrm{mmH}_{2} \mathrm{O}$ was introduced into the uterine horn.

$\mathrm{PGE}_{2}$ and $\mathrm{PGF}_{2 \alpha}$ (Ono Pharmaceutical Co., Ltd., Osaka) were injected into the lateral ventricle at a constant volume of $10 /$. B. Both PGs were dissolved before use in small amounts of absolute ethanol and diluted by artificial cerebrospinal fluid (CSF). The composition (in $\mathrm{mEq} / 1$ ) of the CSF was as follows: $\mathrm{Na}^{+} ; 150 ; \mathrm{K}^{+} ; 3, \mathrm{Ca}^{++} ; 2.3, \mathrm{Mg}^{++} ; 1.6, \mathrm{Cl}^{-} ; 135$, $\mathrm{HCO}_{3}{ }^{-} ; 21, \mathrm{HPO}_{4}{ }^{--} ; 0.5$. Ethanol concentration of 10 nmoles $/ 10 / 1$ of $\mathrm{PGE}_{2}$ and $\mathrm{PGF}_{2 . \alpha}$ was 3\%. Oxytocin (Atonin-O, Teikoku Hormone MFG Co., Ltd., Tokyo) was diluted with saline for i.v. administration in a volume of $0.1 \mathrm{ml}$. When $3 \%$ ethanol or CSF was 